\title{
Canonical correlation for morphoagronomic and bromatological traits in silage corn genotypes
}

Jocarla Ambrosim Crevelari ${ }^{1 \star}$, Nayara Norrene Lacerda Durães ${ }^{1}$, Paulo Ricardo dos Santos ${ }^{1}$, Flávio Henrique Vidal Azevedo², Laila Cecília Ramos Bendia², Sandra da Costa Preisigke ${ }^{1}$, Gabriel Moreno Bernardo Gonçalves ${ }^{1}$, José Arantes Ferreira Junior ${ }^{1}$, Messias Gonzaga Pereira ${ }^{1}$

1.Universidade Estadual do Norte Fluminense Darcy Ribeiro - Laboratório de Melhoramento Genético Vegetal Campos dos Goytacazes (RJ), Brazil.

2.Universidade Estadual do Norte Fluminense Darcy Ribeiro - Laboratório de Zootecnia - Campos dos Goytacazes (RJ), Brazil.

ABSTRACT: The aim of this study is to assess whether there is linear dependence between groups of morphoagronomic and bromatological traits in hybrid silage corn. Nineteen topcross hybrids and five checks were assessed in two different environments in Campos dos Goytacazes and Itaocara counties, Rio de Janeiro State, during the growing seasons 2013/2014. The study followed a randomized blocks design with four replicates. The phenotypic and canonical correlations between the groups of seven morphoagronomic and five bromatological traits were assessed. There is linear dependence between the group pairs of morphoagronomic, and bromatological variables. The morphoagronomic trait green mass yield can be adopted in indirect selection processes to indicate the increased bromatological quality of maize silage based on features such as crude protein, neutral detergent fiber, lignin, crude fat and mineral matter. Topcross hybrids UENF-2208 and UENF-2209 presented high potential for silage yield in the North and Northwest Regions.

Key words: Zea mays L., topcross, tester, multicollinearity. 


\section{INTRODUCTION}

The United States is the biggest corn (Zea mays L.) producer in the world. The country is followed by China and Brazil, with estimated production of $386.74,216.00$ and 83.88 million tons, respectively (USDA 2016). The maize crop area estimated for the $2017 / 2018$ growing season in Brazil is 16,969 thousand hectares with yield estimated at $4,967 \mathrm{~kg} \cdot \mathrm{ha}^{-1}$, which would result in the production of 82,927.9 thousand tons (Conab 2018). According to estimates, approximately 800,000 hectares in Brazil are planted with maize exclusively grown for silage production (Moraes and Santos 2008); this area has been constantly growing in recent years.

It is worth noticing that most breeding programs developed in the country do not emphasize the development of cultivars for silage production. Often, the best hybrids for grain production are also recommended for silage production (Mendes et al. 2008); therefore the lack of information about agronomic response and nutritional values became a barrier to the selection of hybrid corn for silage production. The morfoagronomic and bromatological traits of genetic materials are of crucial importance for silage (Rosa et al. 2004).

The association between features of economic interest is essential to enable genetic improvement programs, mainly to investigate correlated responses that can help identifying changes in a given trait, which would have resulted from selection processes based on a different trait (Cruz et al. 2012). According to Cruz et al. (2012), although simple correlation coefficients are very useful to quantify the magnitude and direction of factors influencing the determination of complex traits, they do not show the relative importance of the direct and indirect effects resulting from these factors.

It is essential identifying and quantifying the association between morphoagronomic and bromatological traits in order to improve the efficiency of selection processes focused on meeting most aims of maize breeding programs. The canonical correlation analysis allows investigating the association between two groups of variables (Cruz et al. 2012) in order to enable the selection of a more appropriate plant ideotype.

The canonical correlation analysis is an uncomplicated way to reduce the complexity of associating two sets of variables (Trugilho et al. 2003). It can be used to estimate the maximum correlation between two complexes of variables composed by linear combinations of several traits, as well as to enable the evaluation of interrelationships between two complexes determined by an arbitrary number of traits. This analysis is often used in exploratory studies comprising a large number of variables to investigate linear combinations presenting increased correlation (Cruz et al. 2012; Silva et al. 2007; Witten and Tibshirani 2009).

Canonical correlations have been used to elucidate relationships in Saccharum officinarum (Silva et al. 2009), Carica papaya (Oliveira et al. 2010), guava (Santos et al. 2017), Spondias purpurea (Giles et al. 2016), Ricinus communis (Brum et al. 2011), Triticum sativum L. (Carvalho et al. 2015), Lolium Multiflorum (Müller et al. 2012) and Zea mays L. (Souza et al. 2015). However there is no information on the associations between groups of traits their simultaneous selection in corn improvement for silage production purposes.

The aim of this study was to investigate whether there is linear dependence between morphoagronomic and bromatological traits in hybrid corn for silage production.

\section{MATERIALS AND METHODS}

The genotypes used came from the corn collection of Universidade Estadual do Norte Fluminense Darcy Ribeiro - UENF. Nineteen genotypes were selected, all of them belonging to the heterotic group Dent. Each genotype was crossed with a tester - Piranão 12 , which is a broad-based tester also belonging to the heterotic group DENT - in order to generate heterotic group DENT topcross hybrids (Table 1). Topcross hybrids were obtained in an isolated field of Barra do Pomba Island Experimental Station in Itaocara County, Northern Region of Rio de Janeiro State, in March 2013.

Tester Piranão 12 resulted from interpopulation crossings between Cimmyt and Piranão populations, which were already subjected to the $16^{\text {th }}$ reciprocal recurrent selection cycle in the Plant Genetics and Breeding Program of UENF.

Each genotype was cultivated in $10.0 \mathrm{~m}$-long rows $(1.0 \mathrm{~m}$ spacing between rows). Five seeds were sown per linear meter, thus totaling 50 plants per row. Rows were placed $0.20 \mathrm{~m}$ from each other. Female genitor detasseling was performed during the flowering phase - before the spike could release the style-stigma - in order to avoid contamination. The style-stigma only received pollen from the tester (Piranão 12). Harvest was performed 120 days after sowing. 
Table 1. Description of the 19 topcross hybrids, 5 checks and 1 tester used in the experiments.

\begin{tabular}{|c|c|c|c|c|}
\hline Identification & Hybrids & Grain type & Origin & Genetic basis \\
\hline 1 & UENF-2194* & Dent & UENF & Lines \\
\hline 2 & UENF-2195* & Dent & UENF & Lines \\
\hline 3 & UENF-2199* & Dent & UENF & Lines \\
\hline 4 & UENF-2205* & Dent & UENF & Population \\
\hline 5 & UENF-2198* & Dent & UENF & Lines \\
\hline 6 & UENF-2203* & Dent & UENF & Population \\
\hline 7 & UENF-2192* & Dent & UENF & Lines \\
\hline 8 & UENF-2206* & Dent & UENF & Population \\
\hline 9 & UENF-2207* & Dent & UENF & Population \\
\hline 10 & UENF-2208* & Dent & UENF & Lines \\
\hline 11 & UENF-2209* & Dent & UENF & Lines \\
\hline 12 & UENF-2210* & Dent & UENF & Population \\
\hline 13 & UENF- $2200^{*}$ & Dent & UENF & Population \\
\hline 14 & UENF-2202* & Dent & UENF & Population \\
\hline 15 & UENF-2201* & Dent & UENF & Population \\
\hline 16 & UENF-2204* & Dent & UENF & Population \\
\hline 17 & UENF-2193* & Dent & UENF & Lines \\
\hline 18 & UENF-2191* & Dent & UENF & Lines \\
\hline 19 & Piranão $13^{*}$ & Dent & UENF & Population \\
\hline 20 & AG $1051^{\star \star}$ & Dent & Commercial & Hybrid double \\
\hline 21 & UENF-2197*^ & Semi-dent & UENF & Lines \\
\hline 22 & UENF-2196** & Semi-dent & UENF & Lines \\
\hline 23 & $\operatorname{Br} 106^{\star \star}$ & Semi-dent & Commercial & Population \\
\hline \multirow[t]{2}{*}{24} & UENF 506-11** & Semi-dent & UENF & HIP \\
\hline & Piranão $12^{\star \star \star}$ & Dent & UENF & Population \\
\hline
\end{tabular}

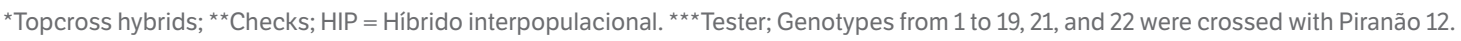

The trials to assess topcross hybrids were simultaneously installed in two different environments: Escola Técnica Estadual Agrícola Antônio Sarlo, in Campos do Goytacazes, Rio de Janeiro State, and Barra do Pomba Island Experimental Station, in Itaocara, Rio de Janeiro State, in the growing seasons 2013/2014.

These environments are located at $21^{\circ} 24^{\prime} 48^{\prime \prime} \mathrm{S}, 41^{\circ} 44^{\prime} 48^{\prime \prime} \mathrm{W}$, $14 \mathrm{~m}$ altitude, with mean rainfall $108.6 \mathrm{~mm}$ and mean temperature $27.27^{\circ} \mathrm{C}$; and at $21^{\circ} 40^{\prime} 09^{\prime \prime} \mathrm{S}, 42^{\circ} 04^{\prime} 34^{\prime \prime} \mathrm{W}$, $60 \mathrm{~m}$ alt, with mean rainfall $183.25 \mathrm{~mm}$ and mean temperature $25.32{ }^{\circ} \mathrm{C}$, respectively (INMET 2017).

The study followed a randomized blocks design with four replicates, each of them with 24 treatments, 19 topcross hybrids and 5 checks (Table 1).

The experimental unit comprised one $5.0 \mathrm{~m}$-long row with $1.0 \mathrm{~m}$ spacing between rows. Each unit had 25 plants per plot with $0.20 \mathrm{~m}$ spacing between pits. Three seeds were sown in each pit ( $5 \mathrm{~cm}$ down in the pit). Trimming was conducted 21 days after emergence and only one plant was left in each pit.

The experiments were structured based on conventional planting system. Crop management was conducted based on recommendations for the culture.

The traits assessed were: number of days for female flowering (FF), measured when $50 \%$ of the plants in the plot presented emerged style-stigma; mean plant height (MPH), measured from the soil level to the tassel insertion knot (in $\mathrm{m}$ ); mean insertion height of the first spike (MIHFS), measured from the soil level to the basis of the upper spike in the culm (in m); mean stem diameter (MSD), measured in the first internode above plant stem (in $\mathrm{m}$ ); spike yield with straw at silage stage (SYWSS) (in $\mathrm{kg} \cdot \mathrm{ha}^{-1}$ ); spike yield without 
straw at silage stage (SYNSS) (in $\mathrm{kg} \cdot \mathrm{ha}^{-1}$ ); grain yield at silage point (GY) (in $\mathrm{kg} \cdot \mathrm{ha}^{-1}$ ); proportion of grains in the green mass (GGM) (in \%); and green mass yield (GMY) (in kg.ha-1).

The MPH, MIHFS and MSD were randomly measured in 6 plants from the plots after flowering feminine whereas the SYWSS, SYNSS, GY and GMY were measured in 15 plants per plot, thus totaling $3.0 \mathrm{~m}$ of each row in the plot. Harvest was performed by cutting the plant $20 \mathrm{~cm}$ from the soil when the grains were at the farenaceous point (3/4 from the milk line) (Restle et al. 2002). SYWSS and SYNSS were measured by weighing the spikes with and without straw at silage stage. GY was obtained by weighing the threshed grain at silage stage. GMY was found by weighing the plants (leaf + stalk + $\mathrm{cob}+$ spike straw + grain) from each plot at harvest. GGM was obtained by the ratio between GY and GMY.

The bromatological analyses were performed in the Zootechny Laboratory (LZNA) of UENF, in Campos dos Goytacazes County, Rio de Janeiro State. The following analyses were carried out: dry matter content (DM), gross protein content (GP), fiber in neutral detergent (FND), gross fat (GF), Lignin (LIG); and mineral matter (MM).

The beam with the 15 plants was weighed after harvest, spikes were removed, thrashed and the weight of the grains was recorded. The straw (leaf + stalk + cob + straw) was processed in forage chopper and homogenized; a subsample of it was collected. The grain and straw samples were dried in ventilated oven at $55^{\circ} \mathrm{C}$ for $72 \mathrm{~h}$ right after harvest. The dried sample (grains + straw) was ground $(1 \mathrm{~mm})$ in Wilye (Logen Scientific - model WLS-3004) mill for bromatological analysis.

The forage samples were tested for gross fat (Method 2003,06) (Thiex et al. 2003), mineral matter (Method 942,05; AOAC, 1990), gross protein (Method AOAC 984,13; Method AOAC 2001,11; AOAC, 1990) (Thiex et al. 2002), fibrous organic matter (aFNDmo) (AOAC 2002,04) (Mertens 2002) and lignin (AOAC 973,18; AOAC, 1990) (Möller 2009). All bromatological variables (DM, GF, FND, GP, LIG and MM) were expressed in $\mathrm{kg} \cdot \mathrm{ha}^{-1}$.

A joint analysis of variance was carried out by taking into account the following statistical model (Eq. 1):

$$
Y_{i j k}=\mu+G_{i}+B / A_{j}+A_{j}+G_{i j}+e_{i j k}
$$

where $\mathrm{Y}_{\mathrm{ijk}}$ is the observation in the $\mathrm{k}^{\text {th }}$ block, which is assessed in the $\mathrm{i}^{\text {th }}$ genotype and in the $\mathrm{j}^{\text {th }}$ environment; $\mu$ is the general constant of the assay; $G_{i}$ is the random effect of the genotype $i$;
$B / A_{j k}$ is the effect of block $K$ on environment $j ; A_{j}$ is the fixed effect of environment $j$; is the interaction effect between genotype $\mathrm{i}$ and environment $\mathrm{j}$; and $\mathrm{e}_{\mathrm{ijk}}$ is the random error associated with observation $\mathrm{Y}_{\mathrm{ijk}}, \mathrm{e}_{\mathrm{ijk}} \sim \operatorname{NID}\left(0, \sigma^{2}\right)$.

Variance components were estimated based on expected mean square values, considering:

Genotypic variance: $\sigma_{\mathrm{g}}^{2}=(\mathrm{QSG}-\mathrm{MSR}) / \mathrm{rl}$;

Phenotypic variance: $\sigma_{\mathrm{f}}^{2}=\mathrm{QSG} / \mathrm{rl}$;

Residual variance: $\sigma_{\mathrm{e}}^{2}=\mathrm{MSR} / \mathrm{rl}$;

Mean heritability of the genotypes: $h_{\bar{x}}^{2}=\sigma_{g}^{2} / \sigma_{f}^{2}$.

Coefficient of experimental variation: $\mathrm{CV}_{\mathrm{e}}(\%)=100\left(\sqrt{\sigma_{\mathrm{e}}^{2} / \overline{\mathrm{x}}}\right)$;

Coefficient of genetic variation: $\mathrm{CV}_{\mathrm{g}}(\%)=100\left(\sqrt{\sigma_{\mathrm{g}}^{2} / \overline{\mathrm{x}}}\right)$;

Variation index: $\mathrm{I}_{\mathrm{V}}(\%)=100\left(\mathrm{CV}_{\mathrm{g}} / \mathrm{CV}_{\mathrm{e}}\right)$;

Accuracy: $\hat{\mathrm{rgg}}=\sqrt{(1-1 / \mathrm{F})}$;

Standard deviation: $\mathrm{DP}=\sqrt{\sigma}$.

where $\mathrm{MSR}=$ mean square of residue; $\mathrm{MSG}=$ mean square of genotype; $r=$ number of repetitions; $1=$ number of environments; and $\mathrm{F}=\mathrm{MSR} / \mathrm{MSG}$ ratio.

Phenotypic correlation coefficients $\left(r_{f}\right)$ :

$$
r_{f}=\left(\operatorname{COV}_{f(x, y)} / \sqrt{\left(\sigma_{f x}^{2} \cdot \sigma_{f y}^{2}\right.}\right)
$$

where $\mathrm{COV}_{\mathrm{f}(\mathrm{x}, \mathrm{y})}=$ phenotypic covariance estimates between traits $x$ and $y$, respectively; $\sigma_{\mathrm{fx}}^{2}=$ phenotypic variance estimates of trait $\mathrm{x}$; and $\sigma_{\mathrm{fy}}^{2}=$ phenotypic variance estimates of trait $\mathrm{y}$.

Multicollinearity diagnosis covered each group of traits (morphoagronomic and bromatological) after the phenotypic correlation matrices were found. Multicollinearity magnitude within each group of traits was checked through number of conditions (NC) and classified based on the criterion by Montgomery and Peck (1982). This process was followed in order to avoid phenotypic and canonical correlation coefficients overestimates (Cruz et al. 2012).

Canonical correlations were estimated between pairs of the groups of morphoagronomic and bromatological traits. The maximum correlation among the linear combinations 
of traits distributed in the group pairs were estimated, as well as the weighing coefficients of the traits in each linear combination.

After finding severe multicollinearity between groups of morphoagronomic and bromatological traits, there were eliminated the traits grain yield at silage point (GY), proportion of grains in the green mass (GGM) and dry matter content (DM) in the groups of morphoagronomic and bromatological traits, respectively. The canonical correlation analysis was applied to traits that remained within each group: morphoagronomic (FF, MPH, MIHFS, MSD, SYWSS, SYNSS and GMY) and bromatological (GP, FND, LIG, CF and MM).

The canonical correlations between group pairs of traits were expressed in coefficient of canonical pairs and in canonical coefficients. The significance of canonical correlations was tested through chi-square test at $(p>0.05)$ significance level. The statistical analyses were conducted in the Genes software (Cruz 2013) and software SAS (SAS Institute Inc. 2013).

\section{RESULTS AND DISCUSSION}

Significant effects were observed in all studied features, indicating genetic variability between genotypes. The effects of the genotype vs. environment interaction were significant in MPH, MSD, GGM, GMY and FND, only. The significant interaction highlights that the response from the genotypes was not coincident in different environments (Table 2).

The assessed hybrids general mean has shown satisfactory outcomes, i.e., it has shown high yield potential in the Northern and Northwestern region of Rio de Janeiro State (Table 2).

Based on genetic parameter estimates, total phenotypic variance recorded genetic variation, fact that indicated genetic variability between genotypes and allowed inferring the possibility of successfully selecting superior hybrids (Maia et al. 2009).

Values estimated for the genotypic variance of morphoagronomic traits ranged from 0.01552 to 11591194.85, whereas the ones estimated for bromatological traits ranged from 450.82 to 1975900.32 (Table 3). The highest estimates concerned variables GMY and DM (11591194.85 and 1975900.32, respectively).
However, it is worth highlighting the proportion of these estimates in residual and phenotypic variances, rather than their magnitude. The proportions of all morphoagronomic variables ranged from $48.30 \%$ to $94.17 \%$ in comparison to the total phenotypic variance. This outcome indicated that the evaluated genotypes presented high genetic variability in the analyzed traits. On the other hand, with respect to bromatological traits, the proportions of genotypic variances in comparison to the phenotypic ones ranged from $54.85 \%$ to $73.23 \%$ (Table 3 ).

The coefficient of experimental variations (CVe) ranged from $2.33 \%$ to $23.12 \%$ in the morphoagronomic traits and from $23.02 \%$ to $27.49 \%$ in the bromatological variables (Table 3). Based on the classification by Fritsche-Neto et al. (2012), the morphoagronomic traits presented great experimental precision. However, the other variables related to yield and to the quality of the forage values were high. This outcome was expected, since these traits are strongly influenced by environmental conditions.

It was observed that the heritability based on the mean has ranged from $48.30 \%$ (SYWSS) to $94.17 \%$ (MPH) in the morphoagronomic traits and from $54.85 \%$ (LIG) to $73.23 \%$ (MM) in the bromatological variables (Table 3).

Therefore, it is possible predicting the possibility of success by selecting the breeding program according to the heritability estimate.

According to Ramalho et al. (2012), the higher the magnitude of the accuracy (closer to 100\%), the better the quality of the experiment and the greater the reliability of the experimental information. The selective accuracy in our study was high (0.69) and indicated the possibility of successfully selecting topcross hybrids. The selective accuracy for the morphoagronomic and bromatological traits ranged from high to very high $(\mathrm{Ac}>0.78)$ in the present study, except for SYWSS, SYNSS, GY, LIG and GF, which were moderate: $0.69,0.69,0.71,0.74$ and 0.77 , respectively (Table 3 ).

Knowing the relationship between the traits of interest is an important aspect for the genotypic selection. Highly correlated traits allow making a selection based on the easily measured traits, leading to similar gain in the other ones (Cruz et al. 2012). Correlation estimates can be used to set the guidelines and to manage corn genetic improvement programs. These results allow achieving gains through indirect selection, which makes the improvement process faster and more effective (Alves et al. 2016). 
Table 2. Summary of the joint analysis of variance applied to eight traits assessed in corn hybrids for silage production. Campos dos Goytacazes and Itaocara, Rio de Janeiro State, growing seasons 2013/2014.

\begin{tabular}{|c|c|c|c|c|c|c|c|c|c|c|c|}
\hline \multirow{3}{*}{ Variation sources } & \multirow{3}{*}{ DF } & \multicolumn{10}{|c|}{ Mean squares } \\
\hline & & $\mathbf{F F}$ & & MPH & MIHFS & MSD & SYWSS & SYNSS & GY & GGM & GMY \\
\hline & & \multicolumn{10}{|c|}{ Morphoagronomic } \\
\hline Block/Environment & 6 & 6.38021 & & 0.15058 & 0.10512 & 7.2901 & 7703347.81 & 3156771.42 & 2326959.02 & 7.24918 & 30492784.42 \\
\hline Genotype (G) & 23 & $28.28782^{\star \star}$ & & $0.21463^{\star \star}$ & $0.13513^{\star \star}$ & $13.3324^{\star \star}$ & $11610599.83^{\star}$ & $6454681.93^{*}$ & $4328791.36^{\star \star}$ & $31.08513^{\star *}$ & $134884400.48^{\star \star}$ \\
\hline Environment (A) & 1 & $84.00521^{\star \star}$ & & $0.3048^{\text {ns }}$ & $0.06901^{\mathrm{ns}}$ & $730.4700^{\star \star}$ & $250189404.08^{\text {ns }}$ & $89257438.02^{\mathrm{ns}}$ & $51268834.50^{\text {ns }}$ & $33.17519^{\text {ns }}$ & $746457228.0^{\text {ns }}$ \\
\hline GXA & 23 & $1.65738^{\text {ns }}$ & & $0.07743^{\star}$ & $0.01416^{\text {ns }}$ & $4.7725^{\star}$ & $7177267.64^{\text {ns }}$ & $3349994.97^{\text {ns }}$ & $1829489.16^{\text {ns }}$ & $12.12635^{\star \star}$ & $70140897.07^{\star}$ \\
\hline Error & 138 & 2.21716 & & 0.0125 & 0.01099 & 2.8877 & 6002445.40 & 3315059.51 & 2121672.55 & 4.39022 & 42154841.64 \\
\hline General Average & & 63.66 & & 2.01 & 1.26 & 22.49 & 11,758 & 8,729 & 6,298 & 19.94 & 31,774 \\
\hline Average hybrids topcross & & 63.65 & & 2.06 & 1.27 & 22.56 & 11,939 & 8,888 & 6,445 & 20.01 & 32,400 \\
\hline Average Checks & & 63.70 & & 1.84 & 1.22 & 22.22 & 11,067 & 8,125 & 5,742 & 19.68 & 29,396 \\
\hline \multirow{3}{*}{ Variation sources } & & & & & \multicolumn{7}{|c|}{ Mean squares } \\
\hline & & \multirow{2}{*}{\multicolumn{3}{|c|}{ DF }} & \multicolumn{2}{|c|}{ DM } & GP & FND & LIG & GF & MM \\
\hline & & & & & \multicolumn{7}{|c|}{ Bromatological } \\
\hline Block/Environment & & \multicolumn{3}{|c|}{6} & \multicolumn{2}{|c|}{7311382.53} & 25421.55 & 2073165.86 & 19269.66 & 4634.52 & 24138.41 \\
\hline Genotype (G) & & \multicolumn{3}{|c|}{23} & \multicolumn{2}{|c|}{$24044017.30^{\star *}$} & $126728.80^{\star \star}$ & $6317563.94^{\star \star}$ & $23075.28^{\star \star}$ & $6075.27^{\star \star}$ & $64491.05^{\star \star}$ \\
\hline Environment $(\mathrm{A})$ & & \multicolumn{3}{|c|}{1} & \multicolumn{2}{|c|}{$155997365.75^{\text {ns }}$} & $499290.00^{\text {ns }}$ & $47096294.08^{\mathrm{ns}}$ & $18703.25^{\mathrm{ns}}$ & $74655.18^{\text {ns }}$ & $87210.75^{\mathrm{ns}}$ \\
\hline GXA & & \multicolumn{3}{|c|}{23} & \multicolumn{2}{|c|}{$11896023.36^{\text {ns }}$} & $57321.37^{\text {ns }}$ & $3934291.94^{\star}$ & $16123.23^{\text {ns }}$ & $3329.26^{\mathrm{ns}}$ & $21208.54^{\mathrm{ns}}$ \\
\hline Error & & \multicolumn{3}{|c|}{138} & \multicolumn{2}{|c|}{8236814.69} & 39222.88 & 2204457.08 & 10404.42 & 2468.68 & 17253.42 \\
\hline General Average & & & & & \multicolumn{2}{|c|}{12,343} & 860 & 6,379 & 370 & 196 & 510 \\
\hline Average hybrids topcross & & & & & \multicolumn{2}{|c|}{12,569} & 871 & 6,504 & 376 & 200 & 519 \\
\hline Average Checks & & & & & \multicolumn{2}{|c|}{11,458} & 815 & 5,904 & 350 & 183 & 478 \\
\hline
\end{tabular}

FF = number of days for flowering; MPH = mean plant height $(\mathrm{m}) ;$ MIHFS = mean insertion height of the first spike $(\mathrm{m})$; MSD = mean stem diameter $(\mathrm{m})$;

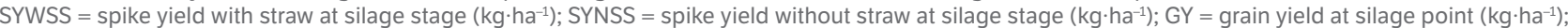

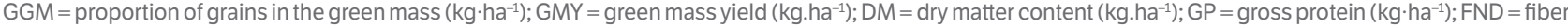
in neutral detergent $\left(\mathrm{kg} \cdot \mathrm{ha}^{-1}\right) ; \mathrm{LIG}=$ Lignin $\left(\mathrm{kg} \cdot \mathrm{ha}^{-1}\right) ; \mathrm{GF}=$ gross fat $\left(\mathrm{kg}^{\mathrm{h}} \mathrm{ha}^{-1}\right) ; \mathrm{MM}=$ and mineral matter $\left(\mathrm{kg} \cdot \mathrm{ha}^{-1}\right) .{ }^{\mathrm{ns}} \mathrm{Not}$ Significant by the $\mathrm{F}$ test; ${ }^{\star \star}$ Significant $(\mathrm{p}<0.01)$ by the $\mathrm{F}$ test; ${ }^{*}$ Significant $(\mathrm{p}<0.05)$ by the $\mathrm{F}$ test.

Phenotypic correlations were used in the analyses canonical correlations since phenotypes are often used as basis for selection purposes. Phenotypically-correlated variables present practical selection value since they have strong genetic components in their phenotypic expressions, which results in gains through visual selection (Andrade et al. 2010; Ferreira et al. 2007).

Pearson's phenotypic correlation estimates for maize genotypes ranged from $r=-0.59$ to $r=0.98$ (Table 4$)$. The morphoagronomic traits presented significant positive and high-magnitude correlation to most bromatological traits - such outcome showed that the morphoagronomic traits influenced the bromatological ones, since they increased simultaneously.

GMY recorded the highest phenotypic correlation coefficients with DM, GP, NDF, LIG, CF and MM $0.96^{* *} ; 0.94^{* *} ; 0.96^{* *} ; 0.93^{* *} ; 0.85^{* *}$ and $0.92^{* *}$, respectively (Table 4 ). These high correlation values showed high linear relationships between green mass yield and traits such as dry matter content, crude protein content, neutral detergent fiber, lignin, crude fat and mineral matter.

Bromatological analyses conducted in laboratory are expensive and laborious for plant breeding programs aimed at producing silage. Thus, it is essential identifying morphoagronomic traits with high potential to silage production in order to enable the shortest evaluation time, the lowest cost and progress in the development of new cultivars.

According to Oliveira et al. (2010), significant correlations indicate the possibility of indirectly selecting important traits based on easily measured agronomic traits. Green mass yield showed significant positive correlations to plant height (0.58), ear yield with straw 
Table 3. Estimates of the genetic parameters of the morphoagronomic and bromatological traits in hybrid corn for silage production. Campos dos Goytacazes and Itaocara, Rio de Janeiro State, growing seasons 2013/2014.

\begin{tabular}{|c|c|c|c|c|c|c|c|c|c|}
\hline \multirow{2}{*}{ Traits } & $\sigma_{\mathrm{g}}^{2}$ & $\sigma_{\mathrm{f}}^{2}$ & $\sigma_{\mathrm{e}}^{2}$ & $\mathrm{CV}_{\mathrm{e}}(\%)$ & $\mathbf{h}_{\mathrm{x}}^{2}$ & $\mathrm{CV}_{g}(\%)$ & $I_{v}(\%)$ & $\hat{\mathbf{r}} \mathbf{g g}$ & DP \\
\hline & \multicolumn{9}{|c|}{ Morphoagronomic } \\
\hline $\mathrm{FF}$ & 3.25883 & 3.53597 & 0.277145 & 2.33 & 92.16 & 2.83 & 1.21 & 0.96 & 1.8 \\
\hline $\mathrm{MPH}$ & 0.02527 & 0.02682 & 0.0015625 & 5.54 & 94.17 & 7.88 & 1.42 & 0.97 & 0.15 \\
\hline MIHFS & 0.01552 & 0.01689 & 0.00137375 & 8.29 & 91.86 & 9.85 & 1.18 & 0.95 & 0.12 \\
\hline MSD & 1.30558 & 1.66655 & 0.36097375 & 7.55 & 78.34 & 5.07 & 0.67 & 0.88 & 1.14 \\
\hline SYWSS & 701019.30414 & 1451324.979 & 750305.6758 & 20.83 & 48.30 & 7.12 & 0.34 & 0.69 & 837.26 \\
\hline SYNSS & 392452.80246 & 806835.24 & 414382.4393 & 20.85 & 48.64 & 7.17 & 0.34 & 0.69 & 626.46 \\
\hline GY & 275889.85224 & 541098.92 & 265209.0689 & 23.12 & 50.98 & 8.33 & 0.36 & 0.71 & 525.25 \\
\hline GGM & 3.33686 & 3.88566 & 0.5487775 & 10.50 & 85.87 & 9.15 & 0.87 & 0.92 & 1.82 \\
\hline \multirow[t]{2}{*}{ GMY } & 11591194.85 & 16860550.06 & 5269355.205 & 20.43 & 68.74 & 10.71 & 0.52 & 0.82 & 3404.58 \\
\hline & \multicolumn{9}{|c|}{ Bromatological } \\
\hline DM & 1975900.32 & 3005502.16 & 1029601.836 & 23.24 & 65.74 & 11.38 & 0.48 & 0.81 & 1405.66 \\
\hline GP & 10938.23 & 15841.10 & 4902.86 & 23.02 & 69.04 & 12.15 & 0.52 & 0.83 & 104.58 \\
\hline FND & 514138.35 & 789695.49 & 275557.135 & 23.27 & 65.10 & 11.24 & 0.48 & 0.80 & 717.03 \\
\hline LIG & 1583.85 & 2884.41 & 1300.5525 & 27.49 & 54.85 & 10.71 & 0.38 & 0.74 & 39.79 \\
\hline GF & 450.82 & 759.40 & 308.585 & 25.28 & 59.34 & 10.79 & 0.42 & 0.77 & 21.23 \\
\hline $\mathrm{MM}$ & 5904.70 & 8061.38 & 2156.6775 & 25.72 & 73.23 & 15.04 & 0.58 & 0.85 & 76.84 \\
\hline
\end{tabular}

FF = number of days for flowering; MPH = mean plant height $(\mathrm{m}) ; \mathrm{MIHFS}=$ mean insertion height of the first spike $(\mathrm{m})$; $M$ SD = mean stem diameter $(\mathrm{m})$;

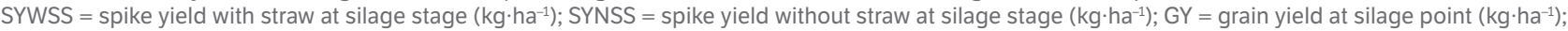

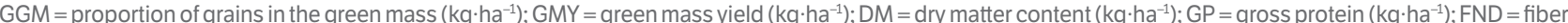
in neutral detergent $\left(\mathrm{kg} \cdot \mathrm{ha} \mathrm{F}^{-1}\right) ; \mathrm{LIG}=\mathrm{Lignin}\left(\mathrm{kg} \cdot \mathrm{ha}^{-1}\right) ; \mathrm{GF}=$ gross fat $\left(\mathrm{kg} \cdot \mathrm{ha}^{-1}\right)$; and $\mathrm{MM}=$ mineral matter $\left(\mathrm{kg} \cdot \mathrm{ha}^{-1}\right)$. $\sigma_{\mathrm{g}}^{2}=\mathrm{genotypic}$ variance; $\sigma_{\mathrm{f}}^{2}=$ phenotypic variance;

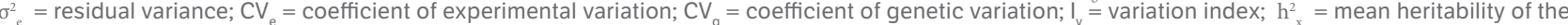
genotypes; $\hat{r} g g=$ Accuracy in genotypes selection. $\mathrm{DP}=$ standard deviation

(0.92), ear yield without straw (0.75) and to grain yield at silage point (0.70) (Table 4$)$. These estimates showed association of inheritable nature between traits. Therefore they can be used in indirect selection processes in breeding programs.

In addition, variables presented positive correlation to each other, fact that showed the complexity of the relationship between traits capable of influencing GMY. This outcome indicates that it is possible to indirectly select plants with higher MPH, SYWSS, SYNSS and GY whenever higher GMY is desired (Table 4).

Therefore, the most regionally-adapted hybrids for green mass yield may be used for silage production when there is no specific information about maize hybrids adopted for this purpose. In addition, grain yield at silage point, ear yield with and without straw at silage point and plant height should be taken into consideration due to the high correlation between these traits and green mass yield.
Correlations between morphoagronomic and bromatological variables in corn for forage production remain poorly assessed, although these variables are essential to select strategies to improve the herein addressed culture. However, correlation magnitude and value are not enough to determine the relations between groups of variables. Canonical correlation is also a valid strategy to dene weights for selection indices (CernRojas et al. 2008).

The study about the association between two groups of characters can be performed through canonical correlation analysis, which aims at determining a linear combination to each group of variables, since these variables are capable of minimizing the correlation between the two groups (Witten and Tibshirani 2009).

The canonical correlation analysis allowed observing that the groups of morphoagronomic and bromatological traits were linearly dependent on each other, i.e., the groups were not independent if one takes into consideration at 
Table 4. Estimates of the coefficients of phenotypic Pearson's correlations between traits in hybrid corn for silage production. Campos dos Goytacazes and Itaocara, Rio de Janeiro State, growing seasons 2013/2014.

\begin{tabular}{|c|c|c|c|c|c|c|c|c|c|c|c|c|c|c|}
\hline & MPH & MIHFS & MSD & SYWSS & SYNSS & GY & GGM & GMY & DM & GP & FND & LIG & GF & MM \\
\hline FF & $-0.30^{\text {ns }}$ & $-0.39^{\text {ns }}$ & $0.72^{\star \star}$ & $0.03^{\text {ns }}$ & $-0.26^{\mathrm{ns}}$ & $-0.17^{\mathrm{ns}}$ & $-0.36^{\mathrm{ns}}$ & $0.14^{\mathrm{ns}}$ & $0.19^{\text {ns }}$ & $0.21^{\mathrm{ns}}$ & $0.21^{\text {ns }}$ & $-0.03^{\text {ns }}$ & $0.10^{\text {ns }}$ & $0.20^{\text {ns }}$ \\
\hline $\mathrm{MPH}$ & & $0.79^{\star \star}$ & $-0.39^{n s}$ & $0.54^{\star \star}$ & $0.65^{\star \star}$ & $0.57^{\star \star}$ & $-0.07^{\mathrm{ns}}$ & $0.58^{\star *}$ & $0.54^{\star \star}$ & $0.52^{\star \star}$ & $0.54^{\star \star}$ & $0.59^{\star \star}$ & $0.48^{*}$ & $0.50^{*}$ \\
\hline MIHFS & & & $-0.46^{\star}$ & $0.43^{*}$ & $0.56^{\star \star}$ & $0.47^{\star}$ & $-0.004^{\text {ns }}$ & $0.45^{*}$ & $0.45^{\star}$ & $0.42^{\star}$ & $0.43^{*}$ & $0.57^{\star \star}$ & $0.47^{\star}$ & $0.44^{\star}$ \\
\hline MSD & & & & $0.22^{\text {ns }}$ & $-0.04^{\text {ns }}$ & $0.04^{\text {ns }}$ & $-0.18^{\mathrm{ns}}$ & $0.19^{\text {ns }}$ & $0.21^{\text {ns }}$ & $0.19^{\text {ns }}$ & $0.23^{\text {ns }}$ & $0.03^{\text {ns }}$ & $0.22^{\text {ns }}$ & $0.19^{\text {ns }}$ \\
\hline SYWSS & & & & & $0.89^{\star \star}$ & $0.83^{\star \star}$ & $-0.19^{\text {ns }}$ & $0.92^{\star \star}$ & $0.87^{\star \star}$ & $0.82^{\star \star}$ & $0.85^{\star \star}$ & $0.87^{\star \star}$ & $0.83^{\star \star}$ & $0.80^{\star \star}$ \\
\hline SYNSS & & & & & & $0.94^{\star \star}$ & $0.15^{\mathrm{ns}}$ & $0.75^{\star \star}$ & $0.68^{\star \star}$ & $0.65^{\star \star}$ & $0.64^{\star \star}$ & $0.80^{\star \star}$ & $0.75^{\star \star}$ & $0.61^{\star \star}$ \\
\hline GY & & & & & & & $0.29^{\mathrm{ns}}$ & $0.70^{\star \star}$ & $0.63^{\star \star}$ & $0.61^{\star \star}$ & $0.55^{\star \star}$ & $0.71^{\star \star}$ & $0.75^{\star \star}$ & $0.56^{\star \star}$ \\
\hline GGM & & & & & & & & $-0.47^{\star}$ & $-0.51^{*}$ & -0.50 * & $-0.59^{\star \star}$ & $-0.37^{\mathrm{ns}}$ & $-0.22^{\mathrm{ns}}$ & $0.52^{\star \star}$ \\
\hline GMY & & & & & & & & & $0.96^{\star \star}$ & $0.94^{\star \star}$ & $0.96^{\star \star}$ & $0.93^{\star \star}$ & $0.85^{\star \star}$ & $0.92^{\star \star}$ \\
\hline DM & & & & & & & & & & $0.97^{\star \star}$ & $0.98^{\star \star}$ & $0.92^{\star \star}$ & $0.90^{\text {** }}$ & $0.96^{\star \star}$ \\
\hline GP & & & & & & & & & & & $0.94^{\star \star}$ & $0.88^{\star \star}$ & $0.88^{\star *}$ & $0.95^{\star \star}$ \\
\hline FND & & & & & & & & & & & & $0.91^{\star \star}$ & $0.84^{\star \star}$ & $0.93^{\star \star}$ \\
\hline LIG & & & & & & & & & & & & & $0.84^{\star \star}$ & $0.87^{\star \star}$ \\
\hline GF & & & & & & & & & & & & & & $0.84^{\star \star}$ \\
\hline
\end{tabular}

$F F=$ number of days for flowering; $M P H=$ mean plant height $(m) ; M I H F S=$ mean insertion height of the first spike $(m) ; M S D=$ mean stem diameter $(m) ;$

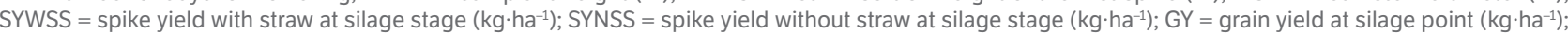

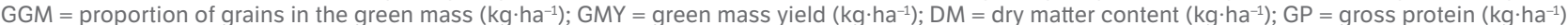
FND = fiber in neutral detergent $\left(\mathrm{kg} \cdot \mathrm{ha}^{-1}\right) ; \mathrm{LIG}=\mathrm{Lignin}\left(\mathrm{kg} \cdot \mathrm{ha}^{-1}\right) ; \mathrm{GF}=$ gross fat $\left(\mathrm{kg} \cdot \mathrm{ha}^{-1}\right)$; and $\mathrm{MM}=$ mineral matter $\left(\mathrm{kg} \cdot \mathrm{ha}^{-1}\right) \cdot{ }^{\mathrm{ns}} \mathrm{Not}$ Significant by the $\mathrm{t}$ test; " Significant $(p<0.01)$ by the t test; ${ }^{*}$ Significant $(p<0.05)$ by the t test.

least the first canonical pair at $(\mathrm{p}<0.01)$ probability level in the chi-square test (Tables 5 ).

The canonical correlation between bromatological and morphoagronomic variables indicated that associations based on the first coefficient of the canonical pair were significant, at $1 \%$ probability level, in the Chi-square test, besides presenting correlation $r=0.98$. Therefore this is the only pair of interest in such associations. Associations between bromatological and morphoagronomic variables are mainly set by variables such as GP, FND, LIG, GF, MM, SYWSS, SYNSS and GMY (Table 5).

Thus, it was possible to identify promising morphoagronomic traits (SYWSS, SYNSS and GMY) for maize genetic improvement since they indicated the quality of bromatological variables.

The coefficient of the first canonical pair showed that plants recording the highest spike yield with or without straw at silage stage and green mass yield significantly increased the gross protein, fiber, lignin, gross fat and mineral matter content in neutral detergent. However, it is necessary to select plants with the highest spike yield with or without straw at silage stage and the highest green mass yield in order to have a cultivar presenting higher gross protein, fiber in neutral detergent, lignin, gross fat and mineral matter accumulation.

Alves et al. (2017) verified that the phenological traits can be used for indirect selection as an indicative of energetic-nutritional quality in grains of maize. Souza et al. (2015) Verified that hybrids with higher plant height, insertion of ear and leaf angle and fewer branches and tassel length are associated with the increase in weight of hundred grains in maize. To increase the grain weight, there should be considered hybrids with greater insertion of the ear, leaf area and shorter length of the tassel.

Although the number of coefficients of canonical pairs is equal to the number of traits of the smallest group, overall only the first two or three canonical functions are reliable, which were used in result interpretation. The significance of at least one coefficient of the canonical pair leads to the conclusion that the groups taken into consideration are dependent, so their coefficient can be used to study the association between traits of the groups.

The aim of the present study was to help genetic improvers better understanding the linear dependence between the morpholoagronomic and bromatological traits in silage corn, since there is lack of studies in this research field.

Accordingly, it is recommended to conduct further studies in order to better understand the association between these groups of traits to get better-quality silage.

Table 6 shows the mean values of morphoagronomic and bromatological traits evaluated in maize hybrids used for silage production, based on the Tukey test. 
Topcross hybrids showed promising results, since they recorded green mass yield ranging from 23263 to $39590 \mathrm{~kg} \cdot \mathrm{ha}^{-1}$ and dry matter content ranging from 8787 to $15792 \mathrm{~kg} \cdot \mathrm{ha}^{-1}$. Among the evaluated treatments, it was possible seeing the superiority of topcross hybrids in most of the evaluated traits in comparison to the controls, with emphasis to green mass yield and dry matter. The herein evaluated UENF-2209 and UENF-2208 topcross hybrids recorded mean GMY values $39540 \mathrm{~kg} \cdot \mathrm{ha}^{-1}$ and $38040 \mathrm{~kg} \cdot \mathrm{ha}^{-1}$, as well as mean DM values $15404 \mathrm{~kg} \cdot \mathrm{ha}^{-1}$ and $15792 \mathrm{~kg} \cdot \mathrm{ha}^{-1}$, respectively (Table 6).

The development of hybrids with good agronomic performance is an important strategy adopted in breeding programs. The evaluation of lines based on their response to hybrid combinations is one of the most important and costly stages of hybrid programs. Topcrosses stand out among the methods developed to facilitate this evaluation process. The use of testers to evaluate the potential of new lines is a routine practice in maize breeding programs. Thus, superior hybrids can be generated based on the identification of crossbreeding lines in order to maximize heterosis.

Heterotic intragroup hybrid combinations of the dentate type were efficient, since they allowed identifying topcross hybrids with good morphoagronomic performance and nutritional value. Thus, they can be indicated for silage production in the Northern/ Northwestern regions of Rio de Janeiro State.

Table 5. Correlation and coefficients of canonical pairs estimated between bromatological and morphoagronomic traits in hybrid corn for silage production. Campos dos Goytacazes and Itaocara, Rio de Janeiro State, growing seasons 2013/2014.

\begin{tabular}{|c|c|c|c|c|c|c|}
\hline & \multirow{2}{*}{ Traits } & \multicolumn{5}{|c|}{ Canonical pairs } \\
\hline & & $1^{\text {st }}$ & $2^{\text {nd }}$ & $3^{\text {rd }}$ & $4^{\text {th }}$ & $5^{\text {th }}$ \\
\hline \multirow{5}{*}{ Bromatological } & Gross protein $\left(\mathrm{kg} \cdot \mathrm{ha}^{-1}\right)$ & 0.9699 & 0.0586 & -0.0034 & 0.2143 & -0.0991 \\
\hline & Fiber in neutral detergent $\left(\mathrm{kg} \cdot \mathrm{ha}^{-1}\right)$ & 0.9807 & 0.1385 & 0.1109 & -0.0687 & 0.0426 \\
\hline & Lignin $\left(\mathrm{kg} \cdot \mathrm{ha}^{-1}\right)$ & 0.9580 & -0.2516 & -0.0333 & -0.1291 & 0.0326 \\
\hline & Gross fat $\left(\mathrm{kg} \cdot \mathrm{ha}^{-1}\right)$ & 0.8708 & -0.2330 & 0.3548 & 0.2403 & -0.0601 \\
\hline & Mineral matter $\left(\mathrm{kg} \cdot \mathrm{ha}^{-1}\right)$ & 0.9471 & 0.0874 & 0.0570 & -0.0129 & -0.3030 \\
\hline \multirow{7}{*}{ Morphoagronomic } & Number of days for flowering & 0.1397 & 0.6201 & 0.3221 & 0.5759 & -0.3259 \\
\hline & Mean plant height (m) & 0.5824 & -0.1592 & -0.1405 & -0.1919 & 0.2696 \\
\hline & Mean insertion height of the first spike (m) & 0.4926 & -0.4246 & -0.0054 & -0.4471 & -0.1704 \\
\hline & Mean stem diameter & 0.1543 & 0.3894 & 0.7440 & 0.3775 & -0.0288 \\
\hline & Spike yield with straw at silage stage $\left(\mathrm{kg} \cdot \mathrm{ha}^{-1}\right)$ & 0.8926 & -0.1769 & 0.2013 & 0.0203 & 0.3123 \\
\hline & Spike yield without straw at silage stage $\left(\mathrm{kg} \cdot \mathrm{ha}^{-1}\right)$ & 0.7243 & -0.5365 & 0.1121 & 0.0722 & 0.3889 \\
\hline & Green mass yield $\left(\mathrm{kg} \cdot \mathrm{ha}^{-1}\right)$ & 0.9948 & 0.0070 & 0.0373 & 0.0261 & 0.0896 \\
\hline Canaonical correlation $(r)$ & & $0.98^{* *}$ & $0.87^{\text {ns }}$ & $0.53^{\text {ns }}$ & $0.32^{\mathrm{ns}}$ & $0.23^{\text {ns }}$ \\
\hline Degree of freedom (GL) & & 35 & 24 & 15 & 8 & 3 \\
\hline$\chi^{2}$ & & 118.26 & 43.46 & 11.49 & 3.74 & 1.22 \\
\hline
\end{tabular}

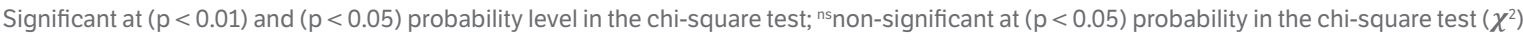

Table 6. Average test between traits in hybrid corn for silage production. Campos dos Goytacazes and Itaocara, Rio de Janeiro State, growing seasons 2013/2014.

\begin{tabular}{|c|c|c|c|c|c|c|c|c|c|}
\hline \multirow{2}{*}{ Hybrids } & \multicolumn{9}{|c|}{ Traits average morphoagronomic } \\
\hline & $\mathbf{F F}$ & MPH & MIHFS & MSD & SYWSS & SYNSS & GY & GGM & GMY \\
\hline UENF-2194 & $67 a$ & 2.08 abcdefg & 1.23 cdefgh & 22.72 abcde & 11798 a & $8356 a b$ & $5812.4 a b$ & $16.70 \mathrm{e}$ & $34782 \mathrm{abcd}$ \\
\hline UENF-2195 & 63.62 bcdef & 1.96 cdefghi & 1.20 cdefgh & 22.24 abcde & $11071 \mathrm{a}$ & $8518.9 \mathrm{ab}$ & $6497.1 \mathrm{ab}$ & 21.00 abcde & 31029 abcd \\
\hline UENF-2199 & 64 bcdef & 1.93 defghi & $1.15 \mathrm{fgh}$ & 23.51 abcde & 12972 a & $8991.4 \mathrm{ab}$ & $6515.6 \mathrm{ab}$ & 18.60 bcde & $35300 \mathrm{abcd}$ \\
\hline UENF-2205 & $65.875 a b$ & 2.01 bcdefg & $1.12 \mathrm{gh}$ & $24.49 a b$ & 13307 a & $9155.6 \mathrm{ab}$ & $6932.4 \mathrm{ab}$ & 18.62 bcde & $37021 \mathrm{abc}$ \\
\hline
\end{tabular}


Table 6. Continuation...

\begin{tabular}{|c|c|c|c|c|c|c|c|c|c|}
\hline \multirow{2}{*}{ Hybrids } & \multicolumn{9}{|c|}{ Traits average morphoagronomic } \\
\hline & $\mathbf{F F}$ & MPH & MIHFS & MSD & SYWSS & SYNSS & GY & GGM & GMY \\
\hline UENF-2198 & $60.75 \mathrm{gh}$ & $2.18 \mathrm{abcd}$ & $1.35 \mathrm{cdef}$ & 21.49 bcde & $11293 a$ & $9267.6 \mathrm{ab}$ & $6468.5 \mathrm{ab}$ & $23.08 a$ & $28315 \mathrm{abcd}$ \\
\hline UENF-2203 & 61.5 efgh & $2.05 \mathrm{abcdefg}$ & 1.33 cdefg & 21.09 cde & 11049 a & $8446.3 a b$ & $5990.8 a b$ & $22.03 a b c$ & $27225 \mathrm{abcd}$ \\
\hline UENF-2192 & $65.5 \mathrm{abc}$ & $1.80 \mathrm{ghi}$ & $1.05 \mathrm{~h}$ & 23.34 abcde & $10072 \mathrm{a}$ & $7744 a b$ & $5638.1 \mathrm{ab}$ & $22.05 \mathrm{abc}$ & $25634 \mathrm{bcd}$ \\
\hline UENF-2206 & 63.75 bcdef & 1.94 defghi & 1.17 efgh & 23.21 abcde & 11885 a & $8906.9 \mathrm{ab}$ & $6653 a b$ & 20.50 abcde & $32416 \mathrm{abcd}$ \\
\hline UENF-2207 & $65.5 \mathrm{abc}$ & 1.88 efghi & $1.15 \mathrm{fgh}$ & $24.89 a$ & $12646 a$ & $9125.5 \mathrm{ab}$ & $6852.3 \mathrm{ab}$ & $21.05 \mathrm{abcd}$ & $32812 \mathrm{abcd}$ \\
\hline UENF-2208 & $65.5 \mathrm{abc}$ & $2.33 a$ & $1.58 \mathrm{a}$ & 21.80 abcde & 12906 a & $9219.1 \mathrm{ab}$ & $6999.5 a b$ & $18.19 \mathrm{de}$ & $38041 \mathrm{ab}$ \\
\hline UENF-2209 & $64.5 \mathrm{abcd}$ & $2.28 a b$ & $1.45 \mathrm{ab}$ & 23.26 abcde & $13598 \mathrm{a}$ & $10028.6 a$ & $6944.3 a b$ & $17.63 \mathrm{de}$ & 39590 a \\
\hline UENF-2210 & $64.5 \mathrm{abcd}$ & $2.23 a b c$ & $1.39 \mathrm{abcd}$ & 22.20 abcde & $13144 \mathrm{a}$ & 9975.3 a & 7313.6 a & $21.07 \mathrm{abcd}$ & $34547 \mathrm{abcd}$ \\
\hline UENF- 2200 & $61.37 \mathrm{fgh}$ & 2.16 abcde & 1.38 abcde & 21.51 bcde & 10884 a & $8018 a b$ & $5557.8 \mathrm{ab}$ & $18 \mathrm{cde}$ & $30790 \mathrm{abcd}$ \\
\hline UENF-2202 & $60.62 \mathrm{gh}$ & 2.13 abcdef & $1.4 a b c$ & $20.78 \mathrm{de}$ & $12505 \mathrm{a}$ & 9991.4 a & 7494.6 a & $22.95 \mathrm{a}$ & $32936 \mathrm{abcd}$ \\
\hline UENF-2201 & $61.37 \mathrm{fgh}$ & 2.14 abcdef & 1.37 abcde & 20.98 cde & 11897 a & $9083.3 \mathrm{ab}$ & $6298 a b$ & 19.39 abcde & $32508 \mathrm{abcd}$ \\
\hline UENF-2204 & $60.25 \mathrm{~h}$ & 2.10 abcdef & 1.34 bcdef & 20.49 e & $12436 a$ & $9573 a b$ & $6887.3 a b$ & 20.54 abcde & $33506 \mathrm{abcd}$ \\
\hline UENF-2193 & $64.75 \mathrm{abcd}$ & 1.88 efghi & $1.07 \mathrm{~h}$ & 22.86 abcde & $9109 a$ & $6344.4 b$ & $4489.9 \mathrm{~b}$ & $17.98 \mathrm{cde}$ & $24583 \mathrm{~cd}$ \\
\hline UENF-2191 & 64.25 abcde & 1.95 cdefghi & 1.18 defgh & 23.57 abcde & 11139 a & $8732.5 a b$ & $6612.1 \mathrm{ab}$ & $21.48 \mathrm{abcd}$ & $30503 \mathrm{abcd}$ \\
\hline Piranão 13 & $64.75 \mathrm{abcd}$ & 2.00 bcdefg & 1.21 cdefgh & $24.26 \mathrm{abc}$ & $13147 a$ & $9405.9 \mathrm{ab}$ & $6501.8 a b$ & 19.33 abcde & $34078 \mathrm{abcd}$ \\
\hline AG 1051 & 62.5 defgh & 1.99 cdefgh & 1.25 bcdefgh & 21.27 bcde & $11197 a$ & $8692 a b$ & $6473.8 \mathrm{ab}$ & $22.87 \mathrm{ab}$ & $27951 \mathrm{abcd}$ \\
\hline UENF-2197 & 63.25 bcdefg & $1.86 \mathrm{fghi}$ & 1.33 bcdefg & $23.91 \mathrm{abcd}$ & 12290 a & $8779.8 \mathrm{ab}$ & $6204 a b$ & 18.48 cde & $33665 \mathrm{abcd}$ \\
\hline UENF-2196 & $64.5 \mathrm{abcd}$ & $1.72 \mathrm{hi}$ & $1.20 \mathrm{cdefgh}$ & 22.96 abcde & $11250 \mathrm{a}$ & $7993.6 \mathrm{ab}$ & $5668.6 a b$ & 18.95 abcde & $30009 \mathrm{abcd}$ \\
\hline $\operatorname{Br} 106$ & 62.75 cdefgh & 1.93 defghi & $1.15 \mathrm{fgh}$ & $20.55 \mathrm{e}$ & $11252 \mathrm{a}$ & $8238.8 \mathrm{ab}$ & $5442.1 \mathrm{ab}$ & $16.71 \mathrm{e}$ & $32096 \mathrm{abcd}$ \\
\hline UENF 506-11 & $65.5 \mathrm{abc}$ & $1.70 \mathrm{i}$ & 1.20 cdefgh & 22.49 abcde & 9350 a & $6927.6 \mathrm{ab}$ & $4926.3 a b$ & $21.39 \mathrm{abcd}$ & $23263 d$ \\
\hline \multirow{2}{*}{\multicolumn{4}{|c|}{ Hybrids }} & \multicolumn{6}{|c|}{ Traits average bromatological } \\
\hline & & & & DM & GP & FND & LIG & GF & MM \\
\hline \multicolumn{4}{|c|}{ UENF-2194 } & $13279 \mathrm{abcd}$ & $969.4 \mathrm{abc}$ & $7242.3 \mathrm{ab}$ & $387.75 a b$ & $205.25 a b$ & $519.63 \mathrm{abcd}$ \\
\hline \multicolumn{4}{|c|}{ UENF-2195 } & $12199 \mathrm{abcd}$ & $850.8 \mathrm{abc}$ & $5987.4 \mathrm{ab}$ & $379.5 \mathrm{ab}$ & $205.88 \mathrm{ab}$ & $518.5 \mathrm{abcd}$ \\
\hline \multicolumn{4}{|c|}{ UENF-2199 } & $13462 \mathrm{abcd}$ & $940.1 \mathrm{abc}$ & $7102.4 a b$ & $406.25 a b$ & $191 a b$ & $586.88 \mathrm{abcd}$ \\
\hline \multicolumn{4}{|c|}{ UENF-2205 } & $14534 \mathrm{abc}$ & $1028.8 \mathrm{ab}$ & $7203.8 \mathrm{ab}$ & $385.25 \mathrm{ab}$ & $232.38 \mathrm{ab}$ & $602.88 \mathrm{abc}$ \\
\hline \multicolumn{4}{|c|}{ UENF-2198 } & $10745 \mathrm{abcd}$ & $788.1 \mathrm{abc}$ & $5544.3 \mathrm{ab}$ & $330 a b$ & $193.25 a b$ & $432.25 \mathrm{bcd}$ \\
\hline \multicolumn{4}{|c|}{ UENF-2203 } & 10136 bcd & 704.8 bc & $5143.9 \mathrm{ab}$ & $299.13 a b$ & $167.38 \mathrm{ab}$ & $396.75 \mathrm{dc}$ \\
\hline \multicolumn{4}{|c|}{ UENF-2192 } & $10374 \mathrm{abcd}$ & 697.9 bc & $5419.5 \mathrm{ab}$ & $304.13 a b$ & $161.38 a b$ & $434.5 \mathrm{bcd}$ \\
\hline
\end{tabular}


Table 6. Continuation...

\begin{tabular}{|c|c|c|c|c|c|c|}
\hline \multirow{2}{*}{ Hybrids } & \multicolumn{6}{|c|}{ Traits average bromatological } \\
\hline & DM & GP & FND & LIG & GF & MM \\
\hline UENF-2206 & $11973 \mathrm{abcd}$ & $789 a b c$ & $6335.4 \mathrm{ab}$ & $352 a b$ & $187.63 a b$ & $488.75 \mathrm{abcd}$ \\
\hline UENF-2207 & 13237 aabcd & $929.5 \mathrm{abc}$ & $6737.9 \mathrm{ab}$ & $362.88 \mathrm{ab}$ & $228.25 \mathrm{ab}$ & $551.5 \mathrm{abcd}$ \\
\hline UENF-2208 & $15792 a$ & 1111.9 a & 7950.9 a & $448.5 \mathrm{ab}$ & $248.63 a$ & $730.25 a$ \\
\hline UENF-2209 & $15404 a b$ & 1095.4 a & $7982.1 \mathrm{a}$ & 461.25 a & $223.13 a b$ & $678.13 a b$ \\
\hline UENF-2210 & 13207 abcd & $879.8 \mathrm{abc}$ & $6855.1 \mathrm{ab}$ & $430.5 \mathrm{ab}$ & $208.88 a b$ & $513.88 \mathrm{abcd}$ \\
\hline UENF- 2200 & $11612 \mathrm{abcd}$ & $793.4 \mathrm{abc}$ & $6261 \mathrm{ab}$ & $362.38 \mathrm{ab}$ & $169 \mathrm{ab}$ & $490.63 \mathrm{abcd}$ \\
\hline UENF-2202 & 11936 abcd & $823.8 \mathrm{abc}$ & $5977.4 \mathrm{ab}$ & $400.38 \mathrm{ab}$ & $200.38 a b$ & $473.5 \mathrm{bcd}$ \\
\hline UENF-2201 & $13375 \mathrm{abcd}$ & $866.6 \mathrm{abc}$ & $6942.9 \mathrm{ab}$ & $400.13 \mathrm{ab}$ & $216 \mathrm{ab}$ & $552.38 \mathrm{abcd}$ \\
\hline UENF-2204 & $13245 \mathrm{abcd}$ & $917.4 \mathrm{abc}$ & $6885.8 \mathrm{ab}$ & $414.75 a b$ & $212.88 \mathrm{ab}$ & $508.5 \mathrm{abcd}$ \\
\hline UENF-2193 & $9635 \mathrm{dc}$ & $647.3 c$ & $5179.4 a b$ & $260.63 b$ & $140.88 \mathrm{~b}$ & $359.38 \mathrm{~cd}$ \\
\hline UENF-2191 & $11752 \mathrm{abcd}$ & $860.6 \mathrm{abc}$ & $5894.8 \mathrm{ab}$ & $360.75 a b$ & $202.88 a b$ & $476.75 \mathrm{bcd}$ \\
\hline Piranão 13 & $12933 \mathrm{abcd}$ & $872.8 \mathrm{abc}$ & $6935.1 \mathrm{ab}$ & $401.5 a b$ & $202.38 a b$ & $546 \mathrm{abcd}$ \\
\hline AG 1051 & $10727 \mathrm{abcd}$ & $791.4 \mathrm{abc}$ & $5467.9 \mathrm{ab}$ & $331.75 a b$ & $173.5 \mathrm{ab}$ & $445.88 \mathrm{bcd}$ \\
\hline UENF-2197 & $13628 \mathrm{abcd}$ & $929.9 \mathrm{abc}$ & $7060 a b$ & $429 a b$ & $228.63 a b$ & $567.5 \mathrm{abcd}$ \\
\hline UENF-2196 & $11738 \mathrm{abcd}$ & $831.5 \mathrm{abc}$ & $6051 a b$ & $355.63 a b$ & $192.25 \mathrm{ab}$ & $469.75 \mathrm{bcd}$ \\
\hline $\operatorname{Br} 106$ & $12547 \mathrm{abcd}$ & $918.6 \mathrm{abc}$ & $6406.4 \mathrm{ab}$ & $381.38 a b$ & $182.5 \mathrm{ab}$ & $565 \mathrm{bcd}$ \\
\hline UENF 506-11 & $8787 d$ & $606.3 \mathrm{c}$ & $4539.3 \mathrm{~b}$ & $257.25 b$ & $143 b$ & $347.13 d$ \\
\hline
\end{tabular}

$\mathrm{FF}=$ number of days for flowering; $\mathrm{MPH}=$ mean plant height $(\mathrm{m})$; MIHFS = mean insertion height of the first spike $(\mathrm{m})$; MSD = mean stem diameter $(\mathrm{m})$; SYWSS = spike yield with straw at silage stage $\left(\mathrm{kg} \cdot \mathrm{ha} \mathrm{a}^{-1}\right)$; SYNSS = spike yield without straw at silage stage $\left(\mathrm{kg} \cdot \mathrm{ha}^{-1}\right) ; \mathrm{GY}=$ grain yield at silage point $\left(\mathrm{kg} \cdot \mathrm{ha} \mathrm{h}^{-1}\right)$; GGM = proportion of grains in the green mass $\left(\mathrm{kg} \cdot \mathrm{ha}^{-1}\right) ; \mathrm{GMY}=$ green mass yield $\left(\mathrm{kg} \cdot \mathrm{ha}^{-1}\right) ; \mathrm{DM}=$ dry matter content $\left(\mathrm{kg} \cdot \mathrm{ha} \mathrm{a}^{-1}\right) ; \mathrm{GP}=\mathrm{gross}$ protein $\left(\mathrm{kg} \cdot \mathrm{ha}{ }^{-1}\right) ;$ FND = fiber in neutral detergent $\left(\mathrm{kg} \cdot h a^{-1}\right)$; LIG $=$ Lignin $\left(\mathrm{kg} \cdot h a^{-1}\right) ; G F=$ gross fat $\left(\mathrm{kg} \cdot h a^{-1}\right)$; and $\mathrm{MM}=$ mineral matter $\left(\mathrm{kg} \cdot \mathrm{ha} \mathrm{a}^{-1}\right)$. Average followed by the same letter in the same column did not differ statistically from each other by the Tukey test $p \leq 0.05$.

\section{CONCLUSION}

The results indicate that the topcross hybrids under study presented wide genetic variability.

There is also evidence that green mass yield can be adopted in indirect selection to improve bromatological quality in silage corn.

Topcross hybrids UENF-2208 and UENF-2209 presented high potential for silage yield in the North and Northwest Regions.

\section{ACKNOWLEDGEMENTS}

The authors are grateful to Fundação de Amparo à Pesquisa do Estado do Rio de Janeiro (FAPERJ) and to Universidade
Estadual do Norte Fluminense Darcy Ribeiro (UENF) for their financial support.

\section{AUTHORS' CONTRIBUTION}

Conceptualization, Crevelari J. A. and Pereira M. G.; Methodology, Crevelari J. A., Santos P. R., Preisigke S. C., Vidal F. H. A. and Bendia L. C. R.; Investigation, Crevelari J. A., Gonçalves G. M. B., Ferreira Júnior J. A. and Durães N. N. L.; Writing Original Draft, Crevelari J. A. and Pereira M. G.; Writing - Review and Editing, Crevelari J. A.; Funding Acquisition, Pereira M. G.; Resources, Pereira M. G.; Supervision, Pereira M. G. 


\section{ORCID IDs}

J. A. Crevelari

(iD) https://orcid.org/0000-0001-9466-2803

N. N. L. Durães

(D) https://orcid.org/0000-0003-3112-4543

P. R. Santos

(iD) https://orcid.org/0000-0002-5968-5636

F. H. V. Azevedo

(iD) https://orcid.org/0000-0003-4079-1647

L. C. R. Bendia

(D) https://orcid.org/0000-0003-2455-4895
S. C. Preisigke

(D) https://orcid.org/0000-0002-9176-764X

G. M. B. Gonçalves

(D) https://orcid.org/0000-0003-0103-7553

J. A. Ferreira Junior

(D) https://orcid.org/0000-0002-9178-3930

M. G. Pereira

(iD) https://orcid.org/0000-0002-3463-3768

\section{REFERENCES}

Alves, B. M., Cargnelutti Filho, A., Burin, C. and Toebe, M. (2016). Correlações canônicas entre caracteres agronômicos e nutricionais proteicos e energéticos em genótipos de milho. Revista Brasileira de Milho e Sorgo, 15, 171-185. https://doi.org/10.18512/1980-6477/ rbms.v15n2p171-185

Alves, B. M., Cargnelutti Filho, A., Burin, C. and Toebe, M. (2017). Linear associations among phenological, morphological, productive, and energetic-nutritional traits in corn. Pesquisa Agropecuária Brasileira, 52, 26-35. https://doi.org/10.1590/s0100-204×2017000100004

Andrade, F. A., Rocha, M. M., Gomes, R. L. F., Feire Filho, F. R. and Ramos, S. R. R. (2010). Estimativas de parâmetros genéticos em genótipos de feijão-caupi avaliados para feijão fresco. Revista Ciência Agronômica, 41, 253-258

Brum, B., Lopes, S. J., Storck, L., Lúcio Dal'col, A., Oliveira, P. H. and Milani, M. (2011). Correlações canônicas entre variáveis de semente, plântula, planta e produção de grãos em mamoneira. Ciência Rural, 41, 404-411. https://doi.org/10.1590/S0103-84782011000300007

Carvalho, I. R., Souza, V. Q., Nardino, M., Follmann, D. N., Schmidt, D. and Barreta, D. (2015). Correlações canônicas entre caracteres morfológicos e componentes de produção em trigo de duplo propósito. Pesquisa Agropecuária Brasileira, 50, 690-697. https:// doi.org/10.1590/S0100-204X2015000800007

Cern-Rojas, J. J., Sahagn-Castellanos, J., Castillo-Gonzlez, F., Santacruz-Varela, A. and Crossa, J. (2008). A restricted selection index method based on eigenanalysis. Journal of agricultural, biological, and environmental statistics, 13, 440. https://doi. org/10.1198/108571108X378911
[CONAB] Companhia Nacional de Abastecimento (2018). Acompanhamento da safra brasileira de grãos (2017/2018). Brasília: Companhia Nacional de Abastecimento.

Cruz, C. D. (2013). GENES - a software package for analysis in experimental statistics and quantitative genetics. Acta Scientiarum, 35, 271-276. https://doi.org/10.4025/actasciagron.v35i3.21251

Cruz, C. D., Regazzi, A. J. and Carneiro, P. C. S. (2012). Modelos biométricos aplicados ao melhoramento genético. Viçosa: Editora da UFV.

Ferreira, F. M., Barros, W. S., Silva, F. L., Barbosa, M. H. P., Cruz, C. D. and Bastos, I. T. (2007) Relações fenotípicas e genotípicas entre componentes de produção em cana-de-açúcar. Bragantia, 66, 605- 610. https://doi.org/10.1590/S0006-87052007000400010

Fritsche-Neto, R., Vieira, R. A., Scapim, C. A., Miranda, G. V. and Rezende, L. M. (2012). Updating the ranking of the coefficients of variation from maize Experiments. Acta Scientiarum. Agronomy, 34, 99-101. https://doi.org/10.4025/actasciagron.v34i1.13115

Giles, J. A. D., Oliari, L. S., Rocha, A. C. B., Schmildt, E. R., Silva, W. and França, J. M. (2016). Correlações entre características físicas, químicas e físico-químicas de frutos de cirigueleira. Revista Agro@mbiente On-line, 10, 30-35. https://doi.org/10.18227/19828470ragro.v10i1.2763

[INMET] Instituto Nacional de Meteorologia. (2017). INMET; [accessed 2017 March 20]. http://www.inmet.gov.br/projetos/ rede/pesquisa/instrucao.html 
Maia, M. C. C., Resende, M. D. V., Paiva, J. R., Cavalcanti, J. J. V. and Barros, L. M. (2009). Seleção simultânea para produção, adaptabilidade e estabilidade genotípicas em clones de cajueiro, via modelos misto. Pesquisa Agropecuária Tropical, 39, 43-50.

Mendes, M. C., Pinho, R. G. V., Pereira, M. N., Faria Filho, E. M. and Souza Filho, A. X. (2008). Avaliação de híbridos de milho obtidos do cruzamento entre linhagens com diferentes níveis de degradabilidade da matéria seca. Bragantia, 67, 285-297. https:// doi.org/10.1590/S0006-87052008000200004

Mertens, D. R. (2002). Gravimetric determination of amylase-treated neutral detergent fiber in feeds with refluxing in beakers or crucibles: collaborative study. Journal of AOAC International, 85, 1217-1240.

Möller, J. (2009). Gravimetric determination of acid detergent fiber and lignin in feed: interlaboratory study. Journal of AOAC International, 92, 74-90.

Montgomery, D. C. and Peck, E. A. (1982). Introduction to linear regression analysis. New York: John Wiley.

Moraes, G. J. and Santos, T. A. B. (2008). Produção e qualidade das plantas de milho de textura mole ou dura em diferentes maturidades para silagem. Publicações em Medicina Veterinária e Zootecnia, 2, 1-7.

Müller, L., Manfron, P. A., Medeiros, S. L. P., Rigão, M. H., Bandeira, A. H., Tonetto, C. J. and Dourado-Neto, D. (2012). Correlações de Pearson e canônica entre componentes da matéria seca da forragem e sementes de azevém. Revista Brasileira de Sementes, 34, 086-093. https://doi.org/10.1590/S0101-31222012000100011

Oliveira, E. J., Lima, D. S., Lucena, R. S., Motta, T. B. N. and Dantas, J. L. L. (2010). Correlações genéticas e análise de trilha para número de frutos comerciais por planta em mamoeiro. Pesquisa Agropecuária Brasileira, 45, 855-862. https://doi.org/10.1590/ $\underline{\text { S0100-204X2010000800011 }}$

Ramalho, M. A. P., Ferreira, D. F. and Oliveira, A. C. D. (2012). Experimentação em genética e melhoramento de plantas. Lavras: Editora da UFLA.

Restle, J., Neumann, M., Brondani, I. L., Pascoal, L. L., Silva, J. H. S. Pellegrini, L. G., and Souza, A. N. M. (2002). Manipulação da altura de corte da planta de milho (Zea mays, L.) para ensilagem visando a produção do novilho superprecoce. Revista Brasileira de Zootecnia, 31,1235-1244. https://doi.org/10.1590/S1516-35982002000500021

Rosa, J. R. P., Silva, J. H. S. Restle, J., Pascoal, L. L., Brondani, I. L., Alves Filho, D. C. and Freitas, A. K. (2004). Avaliação do comportamento agronômico da planta e valor nutritivo da silagem de diferentes híbridos de milho (Zea mays L.). Revista Brasileira de Zootecnia, 33, 302-312. https://doi.org/10.1590/S1516-35982004000200005

Santos, P. R. Preisigke, S. C., Viana, A. P., Cavalcante, N. R., Souza, C. M. B., and Amaral Júnior, A. T. (2017). Associations between vegetative and production traits in guava tree full-sib progênies. Pesquisa Agropecuária Brasileira, 52, 303-310. https://doi. org/10.1590/s0100-204×2017000500003

SAS Institute Inc. (2013). SAS, 9.4. Cary-NC: SAS Institute.

Silva, F. L., Pedrozo, C. A., Barbosa, M. H. P., Resense, M. D. V., Peternelli, L. A., Costa, P. M. A. and Vieira, M. S. (2009). Análise de trilha para os componentes de produção de cana-de-açúcar via blup. Revista Ceres, 56, 308-314.

Silva, J. W., Soares, L., Ferreira, P. V., Silva, P. P. and Silva, M. J. C. (2007) Correlações canônicas de características agroindustriais em cana-de-açúcar. Acta Scientiarum Agronomy, 29, 345-349. https://doi.org/10.4025/actasciagron.v29i3.279

Souza, V. Q., Baretta, D., Nardino, M., Carvalho, I. R., Follmann, D. N., Konflanz, V. A. and Schmidt, D. (2015). Variance components and association between corn hybrids morphoagronomic characters. Científica, 43, 246-253. https://doi. org/10.15361/1984-5529.2015v43n3p246-253

Thiex, N. J., Anderson, S. and Gildemeister, B. (2003). Crude fat, hexanes extraction, in feed, cereal grain, and forage (randall/ soxtec/submersion method): collaborative study. Journal of AOAC International, 86, 899-908.

Thiex, N. J., Manson, H., Anderson, S. and Persson, J. Á. (2002). Determination of crude protein in animal feed, forage, grain, and oilseeds by using block digestion with a copper catalyst and steam distillation into boric acid: collaborative study. Journal of AOAC International, 85, 309-317.

Trugilho, P. F., Lima, J. T. and Mori, F. A. (2003). Correlação canônica das características químicas e físicas da madeira de clones de Eucalyptus grandis e Eucalyptus saligna. Cerne, 9, 66-80.

[USDA] U. S. Department of Agriculture. (2016). USDA; [accessed 2018 April 2]. https://www.usda.gov/

Witten, D. M. and Tibshirani, R. J. (2009). Extensions of sparse canonical correlation analysis with applications to genomic data. Statistical Applications in Genetics and Molecular Biology, 8, 1-27. https://doi.org/10.2202/1544-6115.1470 